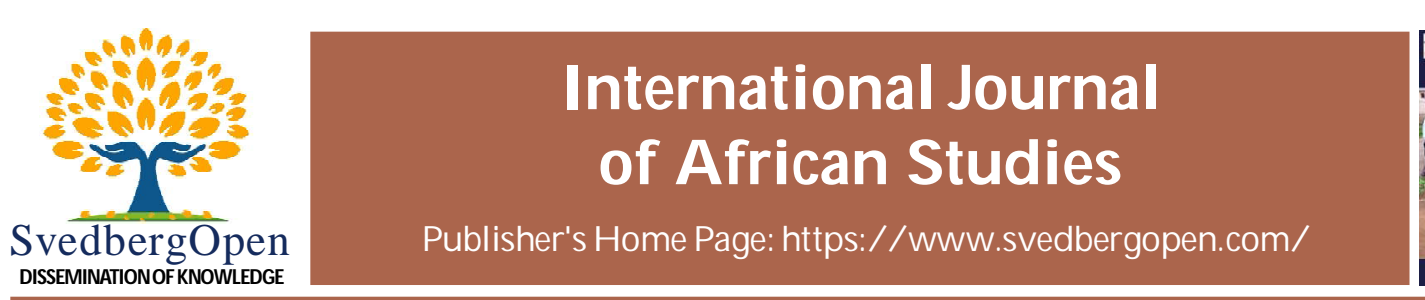

\title{
Differences and Similarities: A Study of Pattern of Disease Related Mortality in Middle-Aged Females of South Africa and India
}

$\mathrm{Uma}^{1 *}$

${ }^{1}$ Senior Assistant Professor, Department of Economics, Lakshmibai College, University of Delhi, Delhi, India. Email: umalbc@lb.du.ac.in

\section{Article Info}

Volume 1, Issue 4, December 2021

Received : 04 May 2021

Accepted : 16 November 2021

Published : 05 December 2021

doi: 10.51483/IJAFRS.1.4.2021.25-41

\section{Introduction}

\begin{abstract}
Middle-aged female population is the stable human resource of any country. They can easily come forward to contribute in economic activities given they are healthy. The paper tries to investigate the disease-based aspect of middle-aged female of South Africa and India which is hindering their healthy status. It looks at the differences and similarities of diseases amongst the middle age females of South Africa and India. The paper examines the leading cause of death of females in the age range of 40-64 in South Africa and India. The paper comes with the conclusion that the number of deaths of females per 100,000 population is high in early years of their middle age and low in later years of the middle age in South Africa. In India the number of deaths of females per 100,000 population is low in early years of their middle age and high in later years of their middle age.
\end{abstract}

Keywords: Female population, Middle age, Mortality, Healthy status, Human resource, Stable

() 2021 Uma. This is an open access article under the CC BY license (https://creativecommons.org/licenses/by/4.0/), which permits unrestricted use, distribution, and reproduction in any medium, provided you give appropriate credit to the original author(s) and the source, provide a link to the Creative Commons license, and indicate if changes were made.

Middle-aged female population is the stable human resource of any country. Female of this age group is mostly free from personal as well as family responsibilities. They attain the desired level of education and training, settles in family life if they wish to and their children are also independent by now. They can easily come forward to contribute in economic activities given they are healthy. The paper tries to investigate the disease-based aspect of middle-aged female of South Africa and India which is hindering their healthy status. These diseases are causing morbidity and mortality to this age group. It looks at the differences and similarities of diseases amongst the middle age females of South Africa and India. The paper tries to find out top 10 diseases which are causing deaths of middle-aged female population of South Africa and India. These top 10 diseases are further categorized under communicable, non-communicable and injuries to understand the severity of the specific diseases in different age groups. The paper examines the leading cause of death of females in the age range of 40-64 in South Africa and India. The study investigates the pattern of the leading cause of death in the years 2000, 2010 and 2019 and tries to suggest a policy proposal to address the issue in both the countries.

\section{Literature Review}

Pandey et al. (2013), opine that Cardiovascular Diseases (CVD) are the most important cause of death amongst middleaged Indian women. To determine prevalence of CVD risk factors and their determinants they performed a nationwide

\footnotetext{
* Corresponding author:Uma, Senior Assistant Professor, Department of Economics, Lakshmibai College, University of Delhi, Delhi, India. Email: umalbc@lb.du.ac.in
} 
study. Greater prevalence of CVD risk factors in urban middle-aged women is explained by greater income and literacy, dietary fat, low physical activity and obesity. Mohan et al. (2016), observe that urbanization is an important determinant of CVD risk. Hsiao et al. (2013), write that in India, Road traffic injuries cause a substantial number of deaths, particularly among pedestrians and other vulnerable road users. Patra (2016), finds that adolescent pregnancy is a serious health threat to young women in India. Kahn (2011) writes that in South Africa Mortality has worsened in virtually all age groups, driven largely by HIV and AIDS. The morbidity profile comprises coexisting infectious and non-communicable diseases - including new infections such as HIV and AIDS, and emerging conditions such as vascular illness and diabetes - together with persisting child diarrhoea and malnutrition, and high levels of interpersonal violence and accidents. Matzopoulos et al. (2015), conducted a retrospective descriptive study of medico-legal post-mortem investigation data from mortuaries using a multistage random sample, stratified by urban and non-urban areas and mortuary size. They calculated age-specific and age-standardized mortality rates for external causes of death. Using, post-mortem reports, they found more than three times as many deaths from homicide and road-traffic injury than had been recorded by vital registration for this period. The homicide rate was similar to the estimate for South Africa from a global analysis, but road-traffic and suicide rates were almost fourfold higher. Maimela et al. (2016), conducted a survey using the WHO "STEP wise approach to the surveillance of non-communicable diseases" (STEPS) methodology. The findings highlighted many facts. Overweight, obesity and high waist circumference were prevalent in females. The cardio-metabolic risk profile was not significantly different between men and women. People who were older than 40 years, overweight or obese and those who consumed alcohol were more likely to be hypertensive. Houle et al. (2014) find that Mortality increased particularly after 2002 for ages 30-69 in South Africa. HIV/AIDS and TB deaths increased and recently plateaued at high levels in people under age 60 . Noncommunicable disease deaths increased among those under 60, and recently also increased among those over 60. Arbyn et al. (2020) write that, cervical cancer was the fourth most common cancer in women in 2018 , ranking after breast cancer ( $2 \cdot 1$ million cases), colorectal cancer ( $0 \cdot 8$ million $)$ and lung cancer ( 0.7 million). Cervical cancer was the leading cause of cancer-related death in women in eastern, western, middle, and southern Africa. Globally, the average age at diagnosis of cervical cancer was 53 years, ranging from 44 years (Vanuatu) to 68 years (Singapore). They opine that, cervical cancer continues to be a major public health problem affecting middle-aged women, particularly in less-resourced countries. Nojilana et al. (2016) find non-communicable disease as the major threat to premature mortality in South Africa. Dagenais et al. (2020) opine that among adults aged 35-70 years, CVD is the major cause of mortality globally. Naghavi et al. (2017) feel that conditions, which cause very substantial mortality in young and middle-aged adults, need to receive much greater policy priority. They find that the majority of countries still lack good-quality vital registration systems to adequately support public policy. Gomes et al. (2017) opine that causes of many of the fifty million annual deaths in low- and middle-income countries remain unknown, as most of the deaths occur at home without medical attention. Ram et al. (2015) opine that in 2014, about two-thirds of India's 10 million deaths per year occurred before age 70 years. About 4.4 million were in adults aged 30-69 years. If 2010 deaths rates were to persist, more than 9 million people in India could die prematurely before the age of 70 years annually by 2030 , the most of any country. Bigaard et al. (2005) find that waist circumference remained strongly and directly associated with all-cause mortality when adjusted for total body fat in middle-aged men and women, suggesting that the increased mortality risk related to excess body fat is mainly due to abdominal adiposity. Sil and Dhillon (2021) investigate the risk factors associated with adult mortality (15-59 years) due to external causes (accidents, suicide, poisoning, homicide, and violence). Findings suggest that the prevalence of these deaths was higher among older adults (age 50 years and above).

Ruan et al. (2018) opine that CVD is one of the leading causes of death worldwide. Their study aimed to investigate the prevalence of two conditions, angina and stroke, and relevant risk factors among older adults in six low- and middleincome countries (LMICs). Smoking was associated with angina in India and South Africa, and was also a risk factor of stroke in South Africa. They observed a stronger association between frequent heavy drinking and stroke in India. Household income was associated with reduced odds of angina in China, India and Russian Federation, however higher household income was a risk factor of angina in South Africa.

\section{Materials and Methods}

We analyzed South Africa and India mortality data for female aged 40-64 years across a 19-year period. The nature of this research is descriptive and analytical. Time period of this study is from 2000 to 2019. The WHO mortality database is used to obtain mortality data from 2000 to 2019 , by age-groups 40-44, 45-49, 50-54, 55-59, and 60-64 years. To analyze causes of mortality, we took data of over two 10-year periods and one 09-year period (2000, 2010 and 2019) to investigate trends in deaths caused by communicable and non-communicable diseases and injury. Top 10 underlying causes of death in all the mentioned age groups are identified and presented through tabular format for analysis. Data is taken 
from Global Health Estimates (2020): Deaths by Cause, Age, Sex, by Country and by Region, 2000-2019. Geneva, (WHO 2020).

South Africa and India are witnessing various types of communicable, non-communicable and injury-based diseases amongst the middle-aged females. The severity of these diseases is so much that it is causing morbidity and mortality. Table 1 indicates the top causes of death in the age group of 40-44 of females of South Africa and India in the year 2000, 2010 and 2019. From the table it is clear that HIV/AIDS remained the top cause of death in this age group in all the three years, although the trend shows that it increased in 2010 from 2000 and then declined very fast in 2019.

The top cause of death in the age group of 40-44 of females in India was tuberculosis in 2000 and 2010. In 2019 ischaemic heart disease was the top reason of deaths for females in India in this age group.

In the context of the top causes of death based on the three classification of causes of death in the age group of 3539 of females in South Africa in 2000, 2010 and 2019 it is clear that HIV/AIDS remained the top cause of death amongst all the types of communicable diseases in this age group in all the three years. In the categories of Injuries; interpersonal violence was the top reason in the age group of 40-44 in the year 2000 and then injury as one of the three categories of disease remained absent in top 10 reasons of deaths for the females of South Africa in 2010 and 2019. It is clear from the table that in the age group of 40-44 cervix uteri cancer was the top most reason of deaths due to non-communicable diseases for females of South Africa in 2000, 2010 and 2019.

Table 1 also reveals the top causes of death based on the three classifications of causes of death in the age group of 40-44 of females in India in the years 2000, 2010 and 2019. From the table it is clear that tuberculosis in 2000, 2010 and 2019 was the top cause of death amongst all the types of communicable diseases in the age groups of 40-44. In the categories of Injuries; self-harm remained the top reason in this age group in all the three years and has increased in 2019. It is clear from the table that in the age group of 40-44 Ischaemic heart disease remained the top most reason of deaths due to noncommunicable diseases for females of India in 2000, 2010 and 2019 and having an increasing trend in all these three years. The other diseases which also exhibited increased trend of deaths in 2019 from 2010 were cervix uteri cancer and breast cancer. A new type of disease that was kidney disease surfaced to top 10 in this age group in India in 2019.

Table 1: Top Ten Causes of Death for Female in the Age group of 40-44 in South Africa and India in 100,000 per Population

\begin{tabular}{|c|c|c|c|c|c|c|c|}
\hline & \multicolumn{3}{|c|}{ SOUTH AFRICA } & & \multicolumn{2}{|c|}{ INDIA } & \multirow[b]{3}{*}{2019} \\
\hline & \multicolumn{2}{|c|}{ AGE GROUP 40-44 } & \multirow[b]{2}{*}{2019} & & \multicolumn{2}{|c|}{ AGE GROUP 40-44 } & \\
\hline & 2000 & 2010 & & & 2000 & 2010 & \\
\hline 1 HIV/AIDS & 615.1 & 731.4 & 216.3 & 1 Tuberculosis & 54.1 & 34.5 & 28.2 \\
\hline 2 Tuberculosis & 59.9 & 56.2 & 37.4 & 2 Self-Harm & 14.7 & 11.8 & 12.5 \\
\hline 3 Interpersonal Violence & 33.6 & $\mathrm{ntt}$ & $\mathrm{ntt}$ & 3 Maternal Conditions & 21.9 & $\mathrm{ntt}$ & $\mathrm{ntt}$ \\
\hline 4 Road Injury & 30.3 & $\mathrm{ntt}$ & $\mathrm{ntt}$ & 4 Diarrhoeal Diseases & 25.3 & 17 & 10.9 \\
\hline 5 Lower Respiratory Infections & 39.7 & 92.7 & 65.3 & 5 Road Injury & $\mathrm{ntt}$ & $\mathrm{ntt}$ & ntt \\
\hline 6 Maternal Conditions & $\mathrm{ntt}$ & ntt & $\mathrm{ntt}$ & 6 Lower Respiratory Infections & ntt & $\mathrm{ntt}$ & ntt \\
\hline 7 Diarrhoeal Diseases & 19 & 36.9 & 28.4 & 7 Interpersonal Violence & $\mathrm{ntt}$ & $\mathrm{ntt}$ & ntt \\
\hline 8 Self harm & $\mathrm{ntt}$ & $\mathrm{ntt}$ & $\mathrm{ntt}$ & 8 Cirrhosis of the liver & $\mathrm{ntt}$ & 10.4 & 9.7 \\
\hline 9 Drug use disorders & $\mathrm{ntt}$ & $\mathrm{ntt}$ & $\mathrm{ntt}$ & 9 Rheumatic Heart Disease & 14 & 12 & 10.2 \\
\hline 10 Meningitis & $\mathrm{ntt}$ & ntt & $\mathrm{ntt}$ & 10 Drowning & ntt & $\mathrm{ntt}$ & ntt \\
\hline 11 Asthma & $\mathrm{ntt}$ & $\mathrm{ntt}$ & $\mathrm{ntt}$ & 11 Ischaemic Heart disease & 28.9 & 29.9 & 31.4 \\
\hline 12 Stroke & 23.6 & 36.3 & 28.7 & 12 Fire, heat and hot substances & $\mathrm{ntt}$ & $\mathrm{ntt}$ & $\mathrm{ntt}$ \\
\hline 13 Cervix Uteri Cancer & 44.2 & 41.9 & 32 & 13 HIV/AIDS & 16.5 & 15 & ntt \\
\hline 14 Breast Cancer & 22.9 & $\mathrm{ntt}$ & $\mathrm{ntt}$ & 14 Stroke & 13.7 & 12.8 & 12.6 \\
\hline 15 Ischaemic Heart disease & 18.3 & 32.8 & 26.7 & 15 Cervix Uteri Cancer & 12.4 & 9.7 & 10.1 \\
\hline \multirow{5}{*}{$\begin{array}{l}16 \text { Diabetes Mellitus } \\
17 \text { Hypertensive heart Disease } \\
18 \text { Kidney Disease } \\
19 \text { Chronic Obstructive, pulmonary disease } \\
20 \text { Cirrhosis of the Liver }\end{array}$} & $\mathrm{ntt}$ & 25.9 & 23 & 16 Breast Cancer & 12.2 & 12.3 & 14.4 \\
\hline & $\mathrm{ntt}$ & $\mathrm{ntt}$ & $\mathrm{ntt}$ & 17 Asthma & $\mathrm{ntt}$ & $\mathrm{ntt}$ & $\mathrm{ntt}$ \\
\hline & $\mathrm{ntt}$ & 28.8 & 27.6 & 18 Chronic Obstructive, pulmonary disease & ntt & $\mathrm{ntt}$ & ntt \\
\hline & $\mathrm{ntt}$ & $\mathrm{ntt}$ & ntt & 19 Kidney Disease & ntt & $\mathrm{ntt}$ & 8.1 \\
\hline & $\mathrm{ntt}$ & 27.4 & 20.8 & 20 Diabetes Mellitus & $\mathrm{ntt}$ & $\mathrm{ntt}$ & $\mathrm{ntt}$ \\
\hline & & & & 21 Falls & ntt & $\mathrm{ntt}$ & $\mathrm{ntt}$ \\
\hline
\end{tabular}

Note: ntt: It signifies, those diseases which are not falling under top 10; Green color is used to denote Communicable diseases; Purple color is used to denote Injuries; Blue color is used to denote Non-communicable diseases; Yellow color indicates that the rate of death due to the specific disease has increased in 2019 in comparison to 2010 or emerged after 2010.

Source: Global Health Estimates 2020: Deaths by Cause, Age, Sex, by Country and by Region, 2000-2019. Geneva, World Health Organization; 2020. (Author's study based on data on top 10 causes of death for female) 
Table 2 shows the trend of Death of female in the age group of 40-44, per 100,000 population due to similar diseases in South Africa and India in the years 2000, 2010 and 2019. In South Africa HIV/AIDS is the main cause of death of females of the age group of 40-44 since 2000 to 2019, whereas this cause is present in 2000 and 2010 in India in this age group but missing in 2019. Overall, the percentage of deaths due to top 10 diseases is higher in South Africa than India. In India Tuberculosis, ischaemic heart disease and diarrhoeal disease, were the top three reasons of death in the age group of 40-44 in 2000 whereas ischaemic heart disease and diarrhoeal disease took second and third position respectively in 2010 and ischaemic heart disease and breast cancer took second and third position respectively in 2019. In case of South Africa, it was HIV/AIDS, tuberculosis and cervix uteri cancer were the top three reasons of deaths of female of this age group in 2000. In 2010 and 2019, lower respiratory infections and tuberculosis occupied second and third positions respectively. In India deaths in this age group was also occurring due to one more disease which were not found in South Africa in top 10; rheumatic heart disease which shows a declining trend from 2000 to 2010 and then in 2019. A new type of disease emerged as kidney disease in top 10 in India in this age group in the year 2019 which was already present in South Africa in 2010 and 2019. In India there was increasing trend of breast cancer, self-harm and cervix uteri cancer in this age group from 2010 to 2019.

Table 2: Trend of Death of Female in the Age Group of 40-44, per 100,000 Population Due to Similar Diseases in South Africa and India

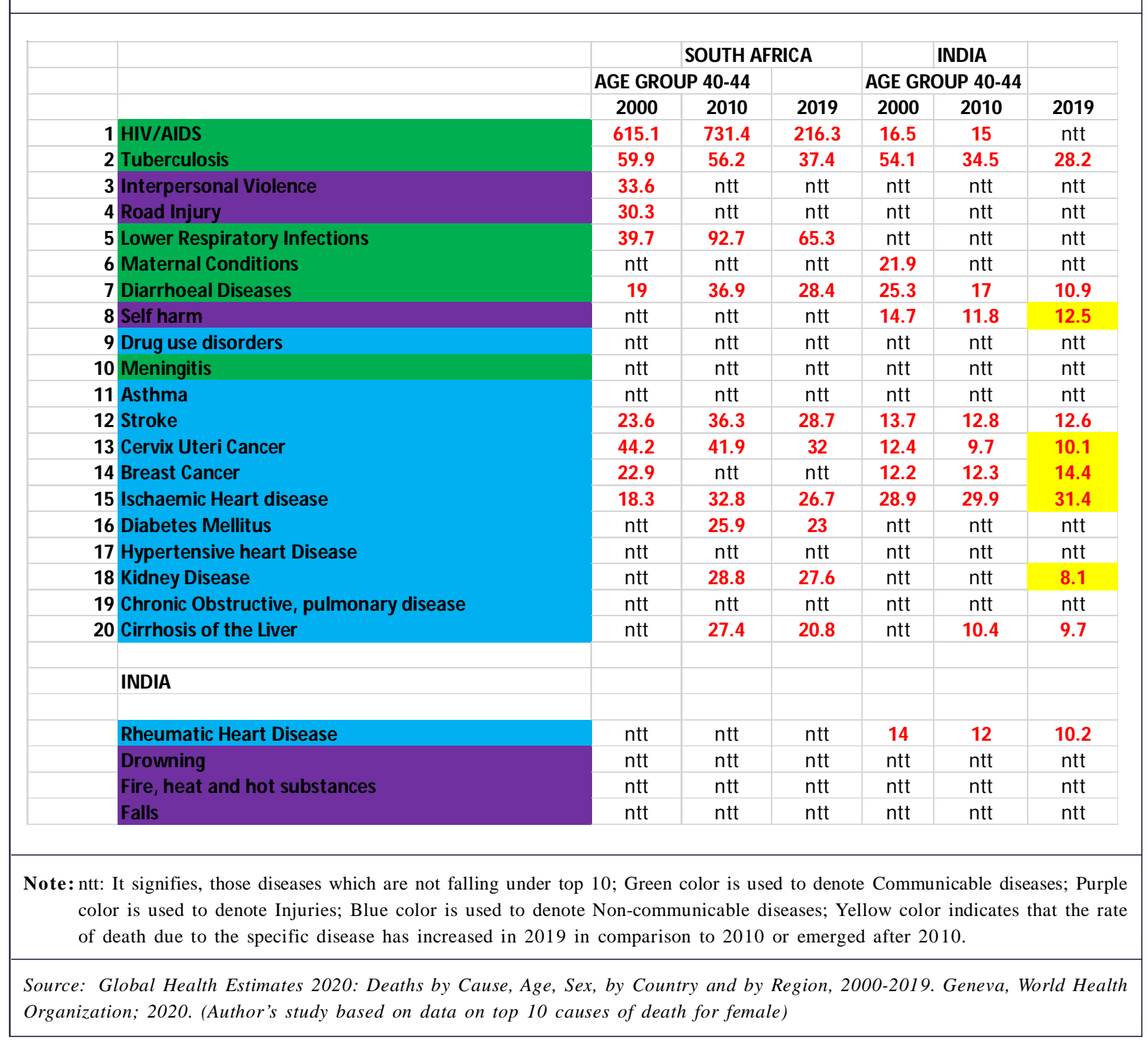

Table 3 indicates the top causes of death in the age group of 45-49 of females of South Africa and India in the year 2000, 2010 and 2019. From the table it is clear that HIV/AIDS remained the top cause of death in this age group in all the three years, although the trend shows that it increased in 2010 from 2000 and then declined very fast in 2019. 
The top cause of death in the age group of 45-49 of females in India was ischaemic heart disease in 2000, 2010 and 2019.

In the context of the top causes of death based on the three classification of causes of death in the age group of 4549 of females in South Africa in 2000, 2010 and 2019 it is clear that HIV/AIDS remained the top cause of death amongst all the types of communicable diseases in this age group in all the three years. In the categories of Injuries; interpersonal violence was the top reason in the age group of 45-49 in the year 2000, 2010 and 2019. It is clear from the table that in the age group of 45-49 stroke was the top most reason of deaths due to non-communicable diseases for females of South Africa in 2000 and 2010 and diabetes mellitus was in 2019.

Table 3 also reveals the top causes of death based on the three classifications of causes of death in the age group of 45-49 of females in India in the years 2000, 2010 and 2019. From the table it is clear that tuberculosis in 2000, 2010 and 2019 was the top cause of death amongst all the types of communicable diseases in the age groups of 45-49. In the categories of Injuries; self-harm remained the top reason in this age group in 2000 and 2019. In 2010 this category was absent in top 10 causes of deaths for the female of India. It is clear from the table that in the age group of 45-49 Ischaemic heart disease remained the top most reason of deaths due to non-communicable diseases for females of India in 2000, 2010 and 2019 and increased in 2010 and then declined in 2019. A new type of disease, ischaemic heart disease surfaced to top 10 in this age group in South Africa in 2019.

Table 3: Top Ten Causes of Death for Female in the Age group of 45-49 in South Africa and India in 100,000 per Population

\begin{tabular}{|c|c|c|c|c|c|c|c|c|}
\hline & & \multicolumn{3}{|c|}{ SOUTH AFRICA } & & \multirow{2}{*}{\multicolumn{2}{|c|}{$\begin{array}{c}\text { INDIA } \\
\text { AGE GROUP 45-49 }\end{array}$}} & \multirow[b]{3}{*}{2019} \\
\hline & & \multicolumn{2}{|c|}{ AGE GROUP 45-49 } & \multirow[b]{2}{*}{2019} & & & & \\
\hline & & 2000 & 2010 & & & 2000 & 2010 & \\
\hline & HIV/AIDS & 409.6 & 579.3 & 200.8 & 1 Tuberculosis & 46.4 & 28.4 & 17.7 \\
\hline & Tuberculosis & 68.2 & 54.9 & 37 & 2 Self-Harm & 15.2 & ntt & 11.3 \\
\hline & Interpersonal Violence & 38.8 & $\mathrm{ntt}$ & $\mathrm{ntt}$ & 3 Maternal Conditions & $\mathrm{ntt}$ & $\mathrm{ntt}$ & $\mathrm{ntt}$ \\
\hline & Road Injury & $\mathrm{ntt}$ & ntt & $\mathrm{ntt}$ & 4 Diarrhoeal Diseases & 43.2 & 26.9 & 15.5 \\
\hline & Lower Respiratory Infections & 63.2 & 93.5 & 55.9 & 5 Road Injury & $\mathrm{ntt}$ & $\mathrm{ntt}$ & $\mathrm{ntt}$ \\
\hline & Maternal Conditions & $\mathrm{ntt}$ & $\mathrm{ntt}$ & $\mathrm{ntt}$ & 6 Lower Respiratory Infections & $\mathrm{ntt}$ & $\mathrm{ntt}$ & $\mathrm{ntt}$ \\
\hline & Diarrhoeal Diseases & 36.3 & 37.9 & 23.7 & 7 Interpersonal Violence & $\mathrm{ntt}$ & $\mathrm{ntt}$ & $\mathrm{ntt}$ \\
\hline & Self harm & $\mathrm{ntt}$ & $\mathrm{ntt}$ & $\mathrm{ntt}$ & 8 Cirrhosis of the liver & 17.6 & 16.9 & 13.5 \\
\hline & Drug use disorders & $\mathrm{ntt}$ & ntt & $\mathrm{ntt}$ & 9 Rheumatic Heart Disease & 19.2 & 16.5 & 11.7 \\
\hline 10 & Meningitis & $\mathrm{ntt}$ & ntt & ntt & 10 Drowning & $\mathrm{ntt}$ & $\mathrm{ntt}$ & $\mathrm{ntt}$ \\
\hline 11 & Asthma & $\mathrm{ntt}$ & ntt & ntt & 11 Ischaemic Heart disease & 59.3 & 63 & 53.2 \\
\hline 12 & Stroke & 62.8 & 58.4 & 40.4 & 12 Fire, heat and hot substances & $\mathrm{ntt}$ & ntt & ntt \\
\hline 13 & Cervix Uteri Cancer & 44.6 & 48.3 & 38.5 & 13 HIV/AIDS & $\mathrm{ntt}$ & ntt & ntt \\
\hline 14 & Breast Cancer & $\mathrm{ntt}$ & $\mathrm{ntt}$ & 25.3 & 14 Stroke & 32.9 & 31.8 & 24.9 \\
\hline 15 & Ischaemic Heart disease & 51.9 & 57 & 38.9 & 15 Cervix Uteri Cancer & 18.3 & 15.1 & 13.1 \\
\hline 16 & Diabetes Mellitus & 38.6 & 54.2 & 41.4 & 16 Breast Cancer & 19.5 & 20.8 & 20.5 \\
\hline 17 & Hypertensive heart Disease & 34 & 32.3 & ntt & 17 Asthma & 18.8 & 13.7 & ntt \\
\hline 18 & Kidney Disease & $\mathrm{ntt}$ & 33.3 & 28.4 & 18 Chronic Obstructive, pulmonary disease & $\mathrm{ntt}$ & $\mathrm{ntt}$ & ntt \\
\hline 19 & Chronic Obstructive, pulmonary disease & $\mathrm{ntt}$ & ntt & ntt & 19 Kidney Disease & $\mathrm{ntt}$ & 14.7 & 13 \\
\hline \multirow{2}{*}{\multicolumn{2}{|c|}{20 Cirrhosis of the Liver }} & $\mathrm{ntt}$ & ntt & $\mathrm{ntt}$ & 20 Diabetes Mellitus & $\mathrm{ntt}$ & $\mathrm{ntt}$ & $\mathrm{ntt}$ \\
\hline & & & & & 21 Falls & $\mathrm{ntt}$ & $\mathrm{ntt}$ & ntt \\
\hline \multicolumn{9}{|c|}{$\begin{array}{l}\text { Note: ntt: It signifies, those diseases which are not falling under top 10; Green color is used to denote Communicable diseases; Purple } \\
\text { color is used to denote Injuries; Blue color is used to denote Non-communicable diseases; Yellow color indicates that the rate } \\
\text { of death due to the specific disease has increased in } 2019 \text { in comparison to } 2010 \text { or emerged after } 2010 \text {. }\end{array}$} \\
\hline \multicolumn{9}{|c|}{$\begin{array}{l}\text { Source: Global Health Estimates 2020: Deaths by Cause, Age, Sex, by Country and by Region, 2000-2019. Geneva, World Health } \\
\text { Organization; 2020. (Author's study based on data on top } 10 \text { causes of death for female) }\end{array}$} \\
\hline
\end{tabular}

Table 4 shows the trend of Death of female in the age group of 45-49, per 100,000 population due to similar diseases in South Africa and India in the years 2000, 2010 and 2019. In South Africa HIV/AIDS is the main cause of death of females of the age group of 40-44 since 2000 to 2019, whereas this cause is absent in India in this age group in all the three years, 2000, 2010 and 2019. Overall, the percentage of deaths due to top 10 diseases is higher in South Africa than India. In India, ischaemic heart disease, Tuberculosis and self-harm, were the top three reasons of death in the age group of 4549 in 2000 whereas ischaemic heart disease, stroke and tuberculosis took first, second and third position respectively in 2010 and ischaemic heart disease, stroke and breast cancer took first, second and third position respectively in 2019. In case of South Africa, it was HIV/AIDS, tuberculosis and lower respiratory infections were the top three reasons of deaths of female of this age group in 2000. In 2010 lower respiratory infections and stroke occupied second and third positions respectively. In 2019 lower respiratory infections and diabetes mellitus occupied second and third positions respectively in South Africa. In India deaths in this age group was also occurring due to one more disease which were 
not found in South Africa in top 10; rheumatic heart disease which shows a declining trend from 2000 to 2010 and then in 2019. A new type of disease emerged as breast cancer in top 10 in South Africa in this age group in the year 2019 which was already present in India in 2000, 2010 and 2019.

Table 4: Trend of Death of Female in the Age Group of 45-49, Per 100,000 Population Due to Similar Diseases in South Africa and India

\begin{tabular}{|c|c|c|c|c|c|c|c|}
\hline & & \multicolumn{3}{|c|}{$\begin{array}{l}\text { SOUTH AFRICA } \\
\end{array}$} & \multicolumn{3}{|c|}{\begin{tabular}{|l|} 
INDIA \\
\end{tabular}} \\
\hline & & \multicolumn{2}{|c|}{ AGE GROUP 45-49 } & & \multicolumn{3}{|c|}{ AGE GROUP 45-49 } \\
\hline & & 2000 & 2010 & 2019 & 2000 & 2010 & 2019 \\
\hline 1 & HIV/AIDS & 409.6 & 579.3 & 200.8 & ntt & ntt & $\mathrm{ntt}$ \\
\hline 2 & Tuberculosis & 68.2 & 54.9 & 37 & 46.4 & 28.4 & 17.7 \\
\hline 3 & Interpersonal Violence & 38.8 & $\mathrm{ntt}$ & ntt & $\mathrm{ntt}$ & ntt & $\mathrm{ntt}$ \\
\hline 4 & Road Injury & $\mathrm{ntt}$ & $\mathrm{ntt}$ & $\mathrm{ntt}$ & $\mathrm{ntt}$ & ntt & ntt \\
\hline 5 & Lower Respiratory Infections & 63.2 & 93.5 & 55.9 & ntt & ntt & ntt \\
\hline 6 & Maternal Conditions & $\mathrm{ntt}$ & $\mathrm{ntt}$ & $\mathrm{ntt}$ & $\mathrm{ntt}$ & $\mathrm{ntt}$ & ntt \\
\hline 7 & Diarrhoeal Diseases & 36.3 & 37.9 & 23.7 & 43.2 & 26.9 & 15.5 \\
\hline 8 & Self harm & $\mathrm{ntt}$ & $\mathrm{ntt}$ & $\mathrm{ntt}$ & 15.2 & $\mathrm{ntt}$ & 11.3 \\
\hline 9 & Drug use disorders & ntt & ntt & ntt & $\mathrm{ntt}$ & ntt & $\mathrm{ntt}$ \\
\hline 10 & Meningitis & ntt & $\mathrm{ntt}$ & $\mathrm{ntt}$ & $\mathrm{ntt}$ & $\mathrm{ntt}$ & $\mathrm{ntt}$ \\
\hline 11 & Asthma & $\mathrm{ntt}$ & ntt & ntt & 18.8 & 13.7 & $\mathrm{ntt}$ \\
\hline 12 & Stroke & 62.8 & 58.4 & 40.4 & 32.9 & 31.8 & 24.9 \\
\hline 13 & Cervix Uteri Cancer & 44.6 & 48.3 & 38.5 & 18.3 & 15.1 & 13.1 \\
\hline 14 & Breast Cancer & $\mathrm{ntt}$ & $\mathrm{ntt}$ & 25.3 & 19.5 & 20.8 & 20.5 \\
\hline 15 & Ischaemic Heart disease & 51.9 & 57 & 38.9 & 59.3 & 63 & 53.2 \\
\hline 16 & Diabetes Mellitus & 38.6 & 54.2 & 41.4 & $\mathrm{ntt}$ & ntt & $\mathrm{ntt}$ \\
\hline 17 & Hypertensive heart Disease & 34 & 32.3 & $\mathrm{ntt}$ & ntt & $\mathrm{ntt}$ & ntt \\
\hline 18 & Kidney Disease & ntt & 33.3 & 28.4 & ntt & 14.7 & 13 \\
\hline 19 & Chronic Obstructive, pulmonary disease & ntt & $\mathrm{ntt}$ & $\mathrm{ntt}$ & $\mathrm{ntt}$ & $\mathrm{ntt}$ & $\mathrm{ntt}$ \\
\hline 20 & Cirrhosis of the Liver & ntt & ntt & ntt & 17.6 & 16.9 & 13.5 \\
\hline & INDIA & & & & & & \\
\hline & Rheumatic Heart Disease & ntt & ntt & ntt & 19.2 & 16.5 & 11.7 \\
\hline & Drowning & $\mathrm{ntt}$ & $\mathrm{ntt}$ & $\mathrm{ntt}$ & $\mathrm{ntt}$ & $\mathrm{ntt}$ & $\mathrm{ntt}$ \\
\hline & Fire, heat and hot substances & ntt & ntt & ntt & ntt & ntt & ntt \\
\hline & Falls & ntt & ntt & ntt & ntt & ntt & ntt \\
\hline
\end{tabular}

Note: ntt: It signifies, those diseases which are not falling under top 10; Green color is used to denote Communicable diseases; Purple color is used to denote Injuries; Blue color is used to denote Non-communicable diseases; Yellow color indicates that the rate of death due to the specific disease has increased in 2019 in comparison to 2010 or emerged after 2010.

Source: Global Health Estimates 2020: Deaths by Cause, Age, Sex, by Country and by Region, 2000-2019. Geneva, World Health Organization; 2020. (Author's study based on data on top 10 causes of death for female)

Table 5 indicates the top causes of death in the age group of 50-54 of females of South Africa and India in the year 2000, 2010 and 2019. From the table it is clear that HIV/AIDS remained the top cause of death in this age group in all the three years, although the trend shows that it increased in 2010 from 2000 and then declined very fast in 2019.

The top cause of death in the age group of 50-54 of females in India was ischaemic heart disease in 2000, 2010 and in 2019. It increased in the year 2019.

In the context of the top causes of death based on the three classification of causes of death in the age group of 5054 of females in South Africa in 2000, 2010 and 2019 it is clear that HIV/AIDS remained the top cause of death amongst all the types of communicable diseases in this age group in all the three years. In the categories of Injuries; interpersonal violence was the top reason in the age group of 50-54 in the year 2000. In 2010 and 2019 the category of injury is absent as top 10 cause of death of female in South Africa. It is clear from the table that in the age group of 50-54 stroke was the 
top most reason of deaths due to non-communicable diseases for females of South Africa. In 2010 and 2019 it was diabetes mellitus was the top cause in this age group.

Table 5 also reveals the top causes of death based on the three classifications of causes of death in the age group of 50-54 of females in India in the years 2000, 2010 and 2019. From the table it is clear that diarrhoeal diseases in 2000 and 2010 was the top cause and in 2019 again tuberculosis was the top reason of death amongst all the types of communicable diseases in the age groups of 50-54. The category of Injuries is absent as the top reason in this age group in 2000,2010 and 2019. It is clear from the table that in the age group of 50-54 Ischaemic heart disease remained the top most reason of deaths due to non-communicable diseases for females of India in 2000, 2010 and 2019 and increased in 2019. There were increase in the deaths due to types of non-communicable diseases such as, stroke, cervix uteri cancer, breast cancer, chronic obstructive, pulmonary disease, kidney disease and diabetes mellitus in this age group in India in 2019.

Table 5: Top Ten Causes of Death for Female in the Age group of 50-54 in South Africa and India in 100,000 per Population

\begin{tabular}{|c|c|c|c|c|c|c|c|}
\hline & \multicolumn{3}{|c|}{ SOUTH AFRICA } & & \multicolumn{2}{|c|}{ INDIA } & \multirow[b]{3}{*}{2019} \\
\hline & \multicolumn{2}{|c|}{ AGE GROUP 50-54 } & \multirow[b]{2}{*}{2019} & & \multicolumn{2}{|c|}{ AGE GROUP 50-54 } & \\
\hline & 2000 & 2010 & & & 2000 & 2010 & \\
\hline 1 HIV/AIDS & 256.9 & 379 & 159.9 & 1 Tuberculosis & 67.4 & 38.7 & 34.2 \\
\hline 2 Tuberculosis & 97.1 & 70.2 & 48.7 & 2 Self-Harm & ntt & $\mathrm{ntt}$ & $\mathrm{ntt}$ \\
\hline 3 Interpersonal Violence & 40.7 & $\mathrm{ntt}$ & $\mathrm{ntt}$ & 3 Maternal Conditions & ntt & $\mathrm{ntt}$ & ntt \\
\hline 4 Road Injury & ntt & $\mathrm{ntt}$ & $\mathrm{ntt}$ & 4 Diarrhoeal Diseases & 76 & 46.1 & 31 \\
\hline 5 Lower Respiratory Infections & 82.3 & 102.4 & 57.5 & 5 Road Injury & $\mathrm{ntt}$ & $\mathrm{ntt}$ & ntt \\
\hline 6 Maternal Conditions & ntt & $\mathrm{ntt}$ & $\mathrm{ntt}$ & 6 Lower Respiratory Infections & ntt & $\mathrm{ntt}$ & ntt \\
\hline 7 Diarrhoeal Diseases & 47 & 42.3 & ntt & 7 Interpersonal Violence & ntt & ntt & ntt \\
\hline 8 Self harm & ntt & $\mathrm{ntt}$ & ntt & 8 Cirrhosis of the liver & 24.3 & 20.2 & ntt \\
\hline 9 Drug use disorders & ntt & $\mathrm{ntt}$ & $\mathrm{ntt}$ & 9 Rheumatic Heart Disease & 26.9 & 21.7 & 21.2 \\
\hline 10 Meningitis & $\mathrm{ntt}$ & ntt & ntt & 10 Drowning & $\mathrm{ntt}$ & $\mathrm{ntt}$ & ntt \\
\hline 11 Asthma & ntt & $\mathrm{ntt}$ & $\mathrm{ntt}$ & 11 Ischaemic Heart disease & 92.8 & 91.2 & 112.5 \\
\hline 12 Stroke & 113.1 & 95.9 & 59.7 & 12 Fire, heat and hot substances & ntt & $\mathrm{ntt}$ & ntt \\
\hline 13 Cervix Uteri Cancer & 55.3 & 53.4 & 41.6 & 13 HIV/AIDS & ntt & $\mathrm{ntt}$ & ntt \\
\hline 14 Breast Cancer & $\mathrm{ntt}$ & $\mathrm{ntt}$ & 32.2 & 14 Stroke & 56.9 & 50 & 57.8 \\
\hline 15 Ischaemic Heart disease & 94.6 & 92.7 & 61 & 15 Cervix Uteri Cancer & 23 & ntt & 20.9 \\
\hline 16 Diabetes Mellitus & 95.1 & 110.3 & 79.9 & 16 Breast Cancer & 26.9 & 27.9 & 36.7 \\
\hline 17 Hypertensive heart Disease & 62.5 & 55.2 & 35.5 & 17 Asthma & 30.5 & 21.7 & $\mathrm{ntt}$ \\
\hline \multirow{3}{*}{$\begin{array}{l}18 \text { Kidney Disease } \\
19 \text { Chronic Obstructive, pulmonary disease } \\
20 \text { Cirrhosis of the Liver }\end{array}$} & $\mathrm{ntt}$ & 45.2 & 35.5 & 18 Chronic Obstructive, pulmonary disease & 33.2 & 26.1 & 28.6 \\
\hline & ntt & $\mathrm{ntt}$ & $\mathrm{ntt}$ & 19 Kidney Disease & ntt & 21.7 & 27.8 \\
\hline & ntt & $\mathrm{ntt}$ & $\mathrm{ntt}$ & 20 Diabetes Mellitus & ntt & $\mathrm{ntt}$ & 26.2 \\
\hline & & & & 21 Falls & ntt & ntt & $\mathrm{ntt}$ \\
\hline
\end{tabular}

Note: ntt: It signifies, those diseases which are not falling under top 10; Green color is used to denote Communicable diseases; Purple color is used to denote Injuries; Blue color is used to denote Non-communicable diseases; Yellow color indicates that the rate of death due to the specific disease has increased in 2019 in comparison to 2010 or emerged after 2010.

Source: Global Health Estimates 2020: Deaths by Cause, Age, Sex, by Country and by Region, 2000-2019. Geneva, World Health Organization; 2020. (Author's study based on data on top 10 causes of death for female)

Table 6 shows the trend of Death of female in the age group of 50-54, per 100,000 population due to similar diseases in South Africa and India in the years 2000, 2010 and 2019. In South Africa HIV/AIDS is the main cause of death of females of the age group of 50-54 since 2000 to 2019, whereas this cause is absent in India in this age group in all the three years, 2000, 2010 and 2019. Overall, the percentage of deaths due to top 10 diseases is higher in South Africa than India. In India, ischaemic heart disease, diarrhoeal diseases and Tuberculosis were the top three reasons of death in the age group of 50-54 in 2000 whereas ischaemic heart disease, stroke and diarrhoeal diseases took first, second and third position respectively in 2010 and ischaemic heart disease, stroke and breast cancer took first, second and third position respectively in 2019. In case of South Africa, it was HIV/AIDS, stroke and tuberculosis were the top three reasons of deaths of female of this age group in 2000. In 2010, diabetes mellitus and lower respiratory infections occupied second and third positions respectively. In 2019 diabetes mellitus and stroke occupied second and third positions respectively in South Africa. In India deaths in this age group was also occurring due to one more disease which were not found in South Africa in top 10; rheumatic heart disease which shows a declining trend from 2000 to 2010 and then in 2019. 


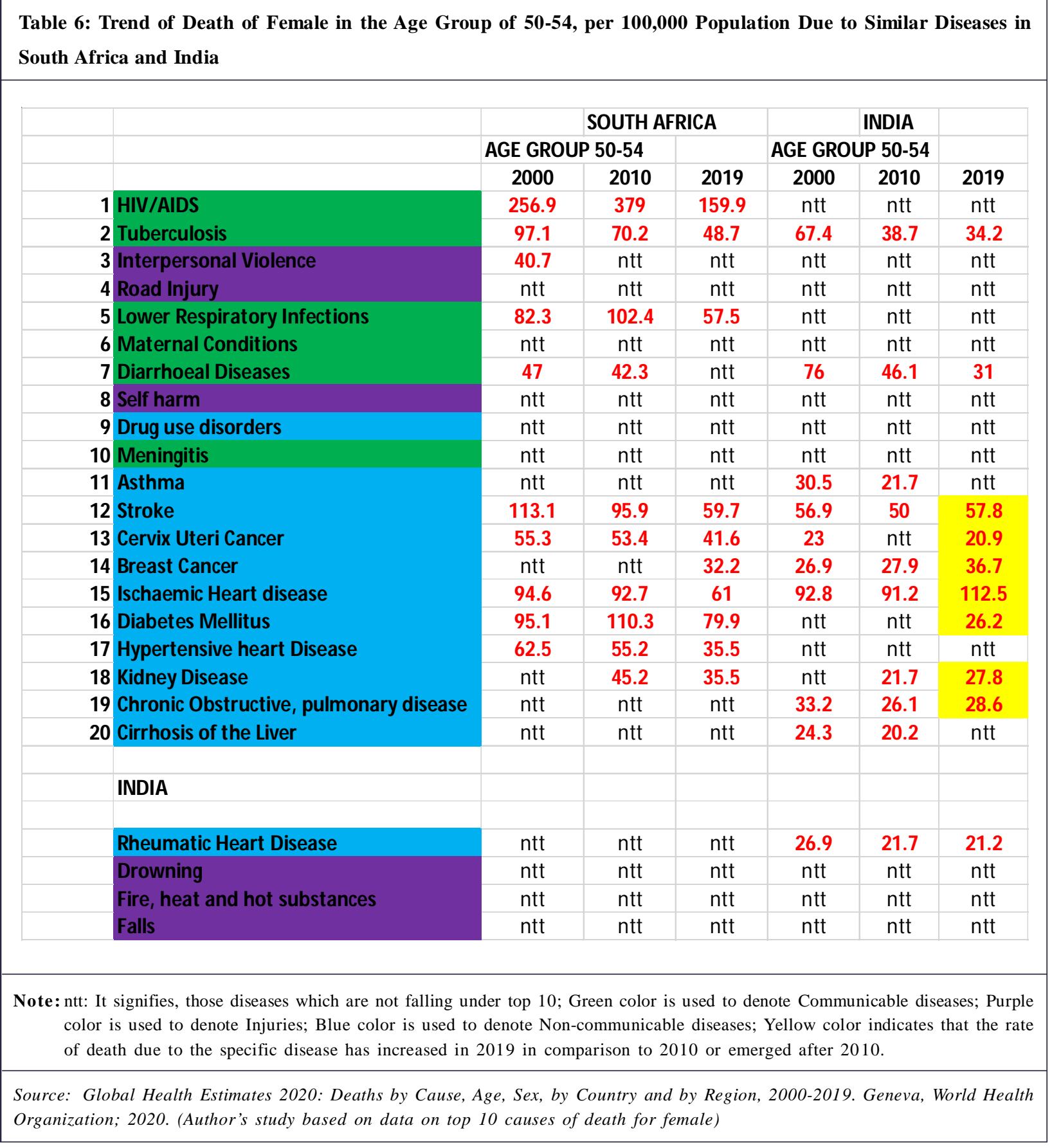

Table 7 indicates the top causes of death in the age group of 55-59 of females of South Africa and India in the year 2000, 2010 and 2019. From the table it is clear that HIV/AIDS remained the top cause of death in this age group in all the three years, although the trend shows that it increased in 2010 from 2000 and then declined very fast in 2019.

The top cause of death in the age group of 55-59 of females in India was ischaemic heart disease in 2000, 2010 and in 2019. It increased in the year 2019.

In the context of the top causes of death based on the three classification of causes of death in the age group of 5559 of females in South Africa in 2000, 2010 and 2019 it is clear that HIV/AIDS remained the top cause of death amongst all the types of communicable diseases in this age group in all the three years. The category of Injury was absent as top 10 cause of death of female in South Africa in all the three years in the age group of 55-59. It is clear from the table that in the age group of 55-59 stroke was the top most reason of deaths due to non-communicable diseases for females of South Africa in 2000. In 2010 and 2019 it was diabetes mellitus was the top cause in this age group.

Table 7 also reveals the top causes of death based on the three classifications of causes of death in the age group of 55-59 of females in India in the years 2000, 2010 and 2019. From the table it is clear that diarrhoeal diseases in 2000,2010 
and 2019 was the top cause of death amongst all the types of communicable diseases in the age groups of 55-59. The category of Injuries is absent as the top reason in this age group in 2000, 2010 and 2019. It is clear from the table that in the age group of 55-59 Ischaemic heart disease remained the top most reason of deaths due to non-communicable diseases for females of India in 2000, 2010 and 2019 and increased in 2019. There were increase in the deaths due to types of non-communicable diseases such as, breast cancer, kidney disease and diabetes mellitus in this age group in India in 2019.

Table 7: Top Ten Causes of Death for Female in the Age group of 55-59 in South Africa and India in 100,000 per Population

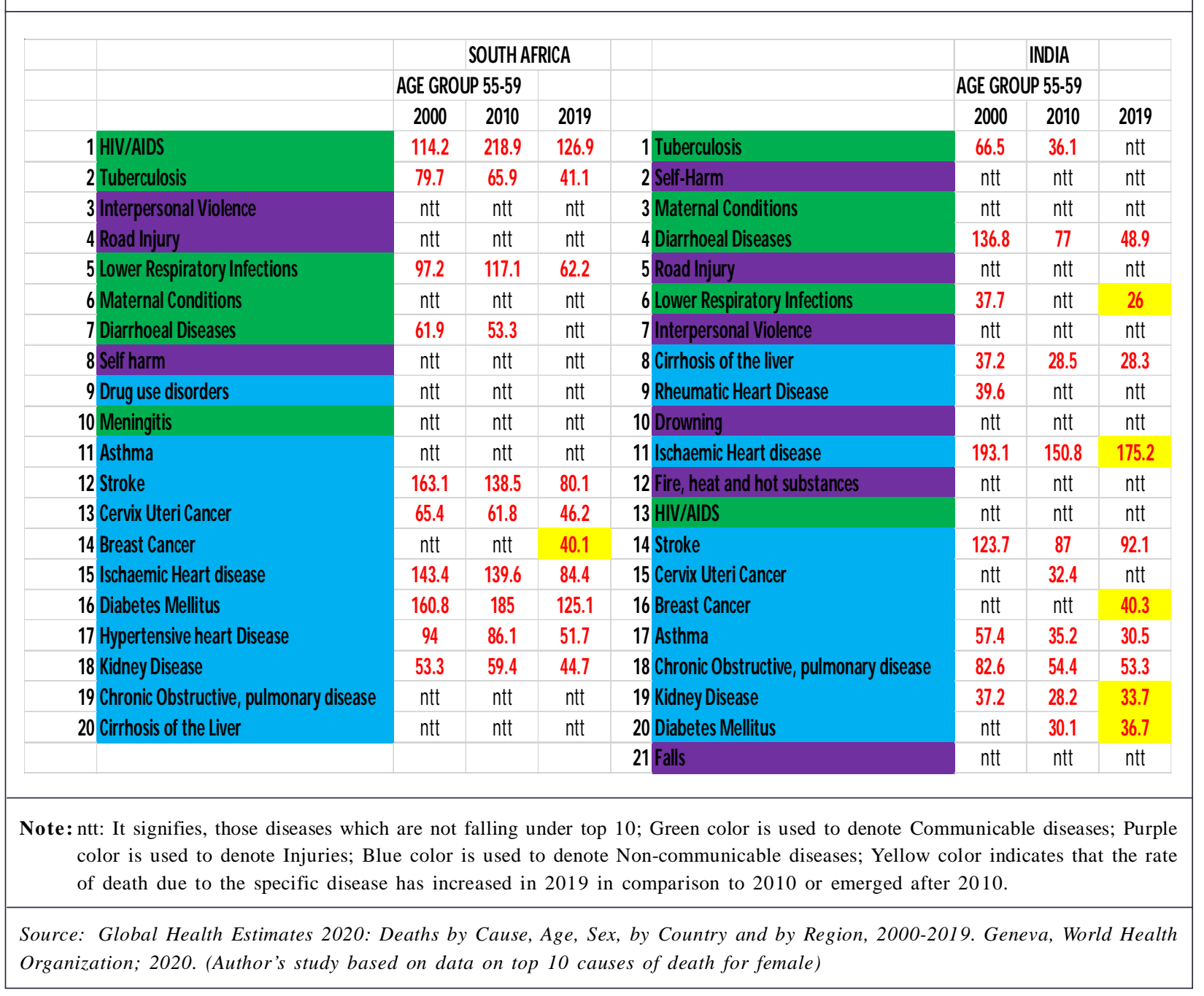

Table 8 shows the trend of Death of female in the age group of 55-59, per 100,000 population due to similar diseases in South Africa and India in the years 2000, 2010 and 2019. In South Africa HIV/AIDS is the main cause of death of females of the age group of 55-59 since 2000 to 2019, whereas this cause is absent in India in this age group in all the three years, 2000, 2010 and 2019. Overall, the percentage of deaths due to top 10 diseases is higher in South Africa than India. In India, ischaemic heart disease, stroke and Tuberculosis were the top three reasons of death in the age group of 55-59 in 2000 whereas ischaemic heart disease, stroke and chronic obstructive, pulmonary disease took first, second and third position respectively in 2010 and 2019. In case of South Africa, it was stroke, diabetes mellitus and ischaemic heart disease, were the top three reasons of deaths of female of this age group in 2000. In 2010, HIV/AIDS, ischaemic heart disease and stroke occupied first, second and third positions respectively. In 2019 HIV/AIDS, diabetes mellitus and ischaemic heart disease, occupied first, second and third positions respectively in South Africa. In India deaths in this age group was also occurring due to one more disease which were not found in South Africa in top 10; rheumatic heart disease in 2000 but in 2010 and in 2019 it was absent.

Table 9 indicates the top causes of death in the age group of 60- of females of South Africa and India in the year 2000, 2010 and 2019. From the table it is clear that stroke in 2000, diabetes mellitus in 2010 and 2019 was the top cause of death in this age group. 
Table 8: Trend of Death of Female in the Age Group of 55-59, per 100,000 Population Due to Similar Diseases in South Africa and India

\begin{tabular}{|c|c|c|c|c|c|c|c|}
\hline & & \multicolumn{3}{|c|}{ SOUTH AFRICA } & \multicolumn{3}{|c|}{ INDIA } \\
\hline & & \multicolumn{2}{|c|}{ AGE GROUP 55-59 } & & \multicolumn{3}{|c|}{ AGE GROUP 55-59 } \\
\hline & & 2000 & 2010 & 2019 & 2000 & 2010 & 2019 \\
\hline \multicolumn{2}{|c|}{1 HIV/ AIDS } & 114.2 & 218.9 & 126.9 & $\mathrm{ntt}$ & $\mathrm{ntt}$ & $\mathrm{ntt}$ \\
\hline \multicolumn{2}{|r|}{2 Tuberculosis } & 79.7 & 65.9 & 41.1 & 66.5 & 36.1 & $\mathrm{ntt}$ \\
\hline \multicolumn{2}{|r|}{3 Interpersonal Violence } & ntt & ntt & $\mathrm{ntt}$ & $\mathrm{ntt}$ & $\mathrm{ntt}$ & $\mathrm{ntt}$ \\
\hline \multicolumn{2}{|r|}{4 Road Injury } & ntt & ntt & ntt & $\mathrm{ntt}$ & $\mathrm{ntt}$ & ntt \\
\hline \multirow{3}{*}{$\begin{array}{l}5 \\
6 \\
7\end{array}$} & Lower Respiratory Infections & 97.2 & 117.1 & 62.2 & 37.7 & ntt & 26 \\
\hline & Maternal Conditions & $\mathrm{ntt}$ & ntt & $\mathrm{ntt}$ & $\mathrm{ntt}$ & $\mathrm{ntt}$ & $\mathrm{ntt}$ \\
\hline & 7 Diarrhoeal Diseases & 61.9 & 53.3 & ntt & $\mathrm{ntt}$ & $\mathrm{ntt}$ & $\mathrm{ntt}$ \\
\hline \multicolumn{2}{|r|}{8 Self harm } & $\mathrm{ntt}$ & $\mathrm{ntt}$ & ntt & ntt & ntt & ntt \\
\hline \multicolumn{2}{|r|}{9 Drug use disorders } & ntt & ntt & ntt & ntt & ntt & $\mathrm{ntt}$ \\
\hline \multicolumn{2}{|r|}{0 Meningitis } & ntt & $\mathrm{ntt}$ & ntt & $\mathrm{ntt}$ & $\mathrm{ntt}$ & $\mathrm{ntt}$ \\
\hline \multirow{2}{*}{$\begin{array}{l}11 \\
12\end{array}$} & Asthma & ntt & ntt & ntt & 57.4 & 35.2 & 30.5 \\
\hline & Stroke & 163.1 & 138.5 & 80.1 & 124 & 87 & 92.1 \\
\hline \multirow{2}{*}{13} & Cervix Uteri Cancer & 65.4 & 61.8 & 46.2 & $\mathrm{ntt}$ & 32.4 & $\mathrm{ntt}$ \\
\hline & Breast Cancer & ntt & ntt & 40.1 & $\mathrm{ntt}$ & $\mathrm{ntt}$ & 40.3 \\
\hline 5 & Ischaemic Heart disease & 143.4 & 139.6 & 84.4 & 193 & 150.8 & 175.2 \\
\hline 165 & Diabetes Mellitus & 160.8 & 185 & 125.1 & $\mathrm{ntt}$ & 30.1 & 36.7 \\
\hline 17 & \multirow{4}{*}{$\begin{array}{l}7 \text { Hypertensive heart Disease } \\
\text { Kidney Disease } \\
\text { Chronic Obstructive, pulmonary disease } \\
\text { Cirrhosis of the Liver }\end{array}$} & 94 & 86.1 & 51.7 & $\mathrm{ntt}$ & $\mathrm{ntt}$ & $\mathrm{ntt}$ \\
\hline 18 & & 53.3 & 59.4 & 44.7 & 37.2 & 28.2 & 33.7 \\
\hline 19 & & ntt & ntt & $\mathrm{ntt}$ & 82.6 & 54.4 & 53.3 \\
\hline 20 & & ntt & ntt & ntt & 37.2 & 28.5 & 28.3 \\
\hline \multicolumn{8}{|c|}{ INDIA } \\
\hline \multicolumn{2}{|r|}{ Rheumatic Heart Disease } & ntt & ntt & ntt & 39.6 & ntt & $\mathrm{ntt}$ \\
\hline & Drowning & ntt & ntt & ntt & $\mathrm{ntt}$ & ntt & ntt \\
\hline \multirow{2}{*}{\multicolumn{2}{|c|}{$\begin{array}{l}\text { Fire, heat and hot substances } \\
\text { Falls }\end{array}$}} & ntt & ntt & ntt & ntt & ntt & $\mathrm{ntt}$ \\
\hline & & ntt & ntt & ntt & ntt & ntt & $\mathrm{ntt}$ \\
\hline
\end{tabular}

Note: ntt: It signifies, those diseases which are not falling under top 10; Green color is used to denote Communicable diseases; Purple color is used to denote Injuries; Blue color is used to denote Non-communicable diseases; Yellow color indicates that the rate of death due to the specific disease has increased in 2019 in comparison to 2010 or emerged after 2010.

Source: Global Health Estimates 2020: Deaths by Cause, Age, Sex, by Country and by Region, 2000-2019. Geneva, World Health Organization; 2020. (Author's study based on data on top 10 causes of death for female)

The top cause of death in the age group of 60-64 of females in India was ischaemic heart disease in 2000, 2010 and in 2019. It increased in the year 2019.

In the context of the top causes of death based on the three classification of causes of death in the age group of 6064 of females in South Africa in 2000, 2010 and 2019 it is clear that lower respiratory infections were the top cause of death amongst all the types of communicable diseases in this age group in all the three years. The category of Injury was absent as top 10 cause of death of female in South Africa in all the three years in the age group of 60-64. It is clear from the table that in the age group of 60-64 stroke was the top most reason of deaths due to non-communicable diseases for females of South Africa in 2000. In 2010 and 2019 it was diabetes mellitus was the top cause in this age group.

Table 9 also reveals the top causes of death based on the three classifications of causes of death in the age group of 60-64 of females in India in the years 2000, 2010 and 2019. From the table it is clear that diarrhoeal diseases in 2000,2010 and 2019 was the top cause of death amongst all the types of communicable diseases in the age groups of 60-64. The category of Injuries in the type of falls emerged under the top 10 reasons of deaths for female in this age group in 2010 and 2019. This type is specific to India and nowhere in the top 10 causes of deaths for females in South Africa in this age group. It is clear from the table that in the age group of 60-64 Ischaemic heart disease remained the top most reason of deaths due to non-communicable diseases for females of India in 2000, 2010 and 2019 and increased in 2019 from 2010. There was increase in the deaths due to types of non-communicable diseases such as, stroke, breast cancer, kidney disease and diabetes mellitus in this age group in India in 2019. 
Table 9: Top Ten Causes of Death for Female in the Age group of 60-64 in South Africa and India in 100,000 per Population

\begin{tabular}{|c|c|c|c|c|c|c|c|}
\hline & \multicolumn{3}{|c|}{ SOUTH AFRICA } & & \multicolumn{2}{|c|}{ INDIA } & \multirow[b]{3}{*}{2019} \\
\hline & \multicolumn{2}{|c|}{ AGE GROUP $60-64$} & \multirow[b]{2}{*}{2019} & & \multicolumn{2}{|c|}{ AGE GROUP $60-64$} & \\
\hline & 2000 & 2010 & & & 2000 & 2010 & \\
\hline 1 HIV/AIDS & ntt & 118.4 & 86.9 & 1 Tuberculosis & 70.8 & 45.4 & $\mathrm{ntt}$ \\
\hline 2 Tuberculosis & 97.9 & 73.4 & 48.6 & 2 SelffHarm & ntt & $\mathrm{ntt}$ & $\mathrm{ntt}$ \\
\hline 3 Interpersonal Violence & ntt & ntt & ntt & 3 Maternal Conditions & ntt & $\mathrm{ntt}$ & $\mathrm{ntt}$ \\
\hline 4 Road Injury & ntt & ntt & ntt & 4 Diarrhoeal Diseases & 259.6 & 161.8 & 101.9 \\
\hline 5 Lower Respiratory Infections & 150.4 & 161.9 & 91 & 5 Road Injury & ntt & ntt & $\mathrm{ntt}$ \\
\hline 6 Maternal Conditions & ntt & ntt & ntt & 6 Lower Respiratory Infections & 70 & 56 & 57.6 \\
\hline 7 Diarrhoeal Diseases & 70.1 & ntt & ntt & 7 Interpersonal Violence & ntt & $\mathrm{ntt}$ & $\mathrm{ntt}$ \\
\hline 8 Self harm & ntt & ntt & ntt & 8 Cirrhosis of the liver & 45.7 & $\mathrm{ntt}$ & $\mathrm{ntt}$ \\
\hline 9 Drug use disorders & ntt & ntt & ntt & 9 Rheumatic Heart Disease & ntt & $\mathrm{ntt}$ & $\mathrm{ntt}$ \\
\hline 10 Meningitis & ntt & ntt & ntt & 10 Drowning & ntt & $\mathrm{ntt}$ & $\mathrm{ntt}$ \\
\hline 11 Asthma & ntt & ntt & ntt & 11 Ischaemic Heart disease & 268.2 & 254.5 & 275.3 \\
\hline 12 Stroke & 318.8 & 260.4 & 155.4 & 12 Fire, heat and hot substances & ntt & ntt & $\mathrm{ntt}$ \\
\hline 13 Cervix Uteri Cancer & 74.7 & 64.5 & 51.2 & 13 HIV/AIDS & ntt & $\mathrm{ntt}$ & $\mathrm{ntt}$ \\
\hline 14 Breast Cancer & ntt & ntt & 50 & 14 Stroke & 205.5 & 171.5 & 175.5 \\
\hline 15 Ischaemic Heart disease & 223.1 & 208.9 & 133.2 & 15 Cervix Uteri Cancer & ntt & ntt & $\mathrm{ntt}$ \\
\hline 16 Diabetes Mellitus & 318.1 & 348.3 & 240 & 16 Breast Cancer & ntt & $\mathrm{ntt}$ & 42.4 \\
\hline 17 Hypertensive heart Disease & 115.7 & 100.8 & 65.7 & 17 Asthma & 84.1 & 62.7 & 50.6 \\
\hline 18 Kidney Disease & 64.3 & 72.3 & 55.4 & 18 Chronic Obstructive, pulmonary disease & 171.6 & 141.2 & 134.2 \\
\hline 19 Chronic Obstructive, pulmonary disease & 68.7 & 60.9 & ntt & 19 Kidney Disease & 47.2 & 42.9 & 49.4 \\
\hline 20 Cirrhosis of the Liver & ntt & ntt & $\mathrm{ntt}$ & 20 Diabetes Mellitus & 62.7 & 62.6 & 72.8 \\
\hline & & & & 21 Falls & ntt & 37.4 & 36.5 \\
\hline
\end{tabular}

Note: ntt: It signifies, those diseases which are not falling under top 10; Green color is used to denote Communicable diseases; Purple color is used to denote Injuries; Blue color is used to denote Non-communicable diseases; Yellow color indicates that the rate of death due to the specific disease has increased in 2019 in comparison to 2010 or emerged after 2010.

Source: Global Health Estimates 2020: Deaths by Cause, Age, Sex, by Country and by Region, 2000-2019. Geneva, World Health Organization; 2020. (Author's study based on data on top 10 causes of death for female)

Table 10 shows the trend of Death of female in the age group of 60-64, per 100,000 population due to similar diseases in South Africa and India in the years 2000, 2010 and 2019. In South Africa stroke is the main cause of death of females of the age group of 60-64 in 2000, in 2010 and 2019 it was diabetes mellitus whereas this cause was not the main cause of death in India in this age group in all the three years, 2000, 2010 and 2019. Overall, the percentage of deaths due to top 10 diseases is higher in South Africa than India. In India, ischaemic heart disease, diarrhoeal diseases and stroke were the top three reasons of death in the age group of 60-64 in 2000 whereas ischaemic heart disease, stroke and diarrhoeal diseases in 2010 and ischaemic heart disease, stroke and chronic obstructive, pulmonary disease took first, second and third position respectively in 2019. In case of South Africa, it was stroke, diabetes mellitus and ischaemic heart disease, were the top three reasons of deaths of female of this age group in 2000. In 2010, diabetes mellitus, stroke and ischaemic heart disease occupied first, second and third positions respectively. In 2019 diabetes mellitus, stroke and ischaemic heart disease, occupied first, second and third positions respectively in South Africa. In India deaths in this age group was also occurring due to one more reason which was not found in South Africa in top 10; falls. It emerged in 2010 and the percentage increased in 2019.

Table 11 highlights about the Leading cause of death for females of South Africa and India in between the age groups of 40-64 in the years 2000, 2010 and 2019. In the case of South Africa HIV/AIDS remained the top reason of deaths in the age groups of 40-44, 45-49 and 50-54 in all the three years that is 2000, 2010 and 2019. In India it was tuberculosis for the age group of 40-44 and for the rest of all the age groups till 64 it was ischaemic heart disease. South Africa witnessed stroke as leading cause of deaths of female in the age groups of 55-59 and 60-64 in the year 2000. In 2010 and 2019 the leading cause of death for the female was HIV/AIDS in the age group of 55-59 and diabetes mellitus in the age group of 60-64. 
Table 10: Trend of Death of Female in the Age Group of 60-64, per 100,000 Population Due to Similar Diseases in South Africa and India

\begin{tabular}{|c|c|c|c|c|c|c|c|}
\hline & & \multicolumn{3}{|c|}{\begin{tabular}{|l} 
SOUTH AFRICA \\
\end{tabular}} & \multicolumn{3}{|c|}{\begin{tabular}{|l|l} 
INDIA \\
\end{tabular}} \\
\hline & & \multicolumn{2}{|c|}{ AGE GROUP 60-64 } & \multirow[b]{2}{*}{2019} & \multicolumn{3}{|c|}{ AGE GROUP 60-64 } \\
\hline & & 2000 & 2010 & & 2000 & 2010 & 2019 \\
\hline $\mathbf{1}$ & 1 HIV/AIDS & ntt & 118.4 & 86.9 & $\mathrm{ntt}$ & $\mathrm{ntt}$ & $\mathrm{ntt}$ \\
\hline 2 & 2 Tuberculosis & 97.9 & 73.4 & 48.6 & 70.8 & 45.4 & ntt \\
\hline 3 & 3 Interpersonal Violence & ntt & ntt & ntt & ntt & $\mathrm{ntt}$ & ntt \\
\hline 4 & 4 Road Injury & ntt & ntt & ntt & ntt & $\mathrm{ntt}$ & ntt \\
\hline 5 & 5 Lower Respiratory Infections & 150.4 & 161.9 & 91 & 70 & 56 & 57.6 \\
\hline 6 & 6 M aternal Conditions & ntt & ntt & ntt & ntt & $\mathrm{ntt}$ & ntt \\
\hline 7 & 7 Diarrhoeal Diseases & 70.1 & ntt & $\mathrm{ntt}$ & 260 & 161.8 & 101.9 \\
\hline 8 & 3 Self harm & ntt & ntt & ntt & ntt & $\mathrm{ntt}$ & ntt \\
\hline 9 & 9 Drug use disorders & $\mathrm{ntt}$ & $\mathrm{ntt}$ & ntt & ntt & $\mathrm{ntt}$ & ntt \\
\hline 10 & Meningitis & $\mathrm{ntt}$ & ntt & $\mathrm{ntt}$ & $\mathrm{ntt}$ & $\mathrm{ntt}$ & $\mathrm{ntt}$ \\
\hline 11 & 1 Asthma & ntt & ntt & ntt & 84.1 & 62.7 & 50.6 \\
\hline 12 & 2 Stroke & 318.8 & 260.4 & 155.4 & 206 & 171.5 & 175.5 \\
\hline 13 & 3 Cervix Uteri Cancer & 74.7 & 64.5 & 51.2 & ntt & $\mathrm{ntt}$ & ntt \\
\hline 14 & 4 Breast Cancer & ntt & ntt & 50 & ntt & $\mathrm{ntt}$ & 42.4 \\
\hline 15 & 5 Ischaemic Heart disease & 223.1 & 208.9 & 133.2 & 268 & 254.5 & 275.3 \\
\hline 16 & 6 Diabetes Mellitus & 318.1 & 348.3 & 240 & 62.7 & 62.6 & 72.8 \\
\hline 17 & 7 Hypertensive heart Disease & 115.7 & 100.8 & 65.7 & ntt & $\mathrm{ntt}$ & ntt \\
\hline 18 & 3 Kidney Disease & 64.3 & 72.3 & 55.4 & 47.2 & 42.9 & 49.4 \\
\hline 19 & 9 Chronic Obstructive, pulmonary disease & 68.7 & 60.9 & ntt & 172 & 141.2 & 134.2 \\
\hline \multirow[t]{7}{*}{20} & Cirrhosis of the Liver & ntt & ntt & ntt & 45.7 & $\mathrm{ntt}$ & ntt \\
\hline & INDIA & & & & & & \\
\hline & & & & & & & \\
\hline & Rheumatic Heart Disease & ntt & ntt & ntt & ntt & $\mathrm{ntt}$ & ntt \\
\hline & Drowning & ntt & ntt & ntt & ntt & ntt & ntt \\
\hline & Fire, heat and hot substances & ntt & ntt & ntt & ntt & ntt & ntt \\
\hline & Falls & ntt & ntt & ntt & ntt & 37.4 & 36.5 \\
\hline $\begin{array}{l}\text { ote: } n t t: \text { It } s \\
\text { color is } \\
\text { of deat }\end{array}$ & $\begin{array}{l}\text { signifies, those diseases which are not falling und } \\
\text { is used to denote Injuries; Blue color is used to } \\
\text { th due to the specific disease has increased in } 20\end{array}$ & $\begin{array}{l}\text { er top } 10 ; \\
\text { denote Non- }\end{array}$ & en color & $\begin{array}{l}\text { sed to de } \\
\text { diseases; }\end{array}$ & ote Con & $\begin{array}{l}\text { unicable } \\
\text { or indica } \\
2010 .\end{array}$ & $\begin{array}{l}\text { ases; } P u \\
\text { hat the }\end{array}$ \\
\hline
\end{tabular}

Table 11: Leading Cause of Death for Females of South Africa and India in Different Age Groups Falling Under the Age 40-64 in the Years 2000, 2010 and 2019

\begin{tabular}{|c|c|c|c|}
\hline & 2000 & 2010 & 2019 \\
\hline $40-445 A$ & HIVIAIDS & HIVIAIDS & HIVIAIDS \\
\hline $40-44 \mathrm{IND}$ & Tuberculosis & Tuberculosis & Tuberculosis \\
\hline $45-49$ SA & HIVIAIDS & HIVIAIDS & HIVIAIDS \\
\hline $45-49 \mathrm{IND}$ & $\begin{array}{l}\text { Ischaemic } \\
\text { Heart } \\
\text { Disease }\end{array}$ & $\begin{array}{l}\text { Ischaemic } \\
\text { Heart Disease }\end{array}$ & $\begin{array}{l}\text { Ischaemic } \\
\text { Heart Disease }\end{array}$ \\
\hline $50-54$ SA & HIVIAIDS & HIVIAIDS & HIVIAIDS \\
\hline $50-54 \mathrm{IND}$ & $\begin{array}{l}\text { Ischaemic } \\
\text { Heart } \\
\text { Disease }\end{array}$ & $\begin{array}{l}\text { Ischaemic } \\
\text { Heart Disease }\end{array}$ & $\begin{array}{l}\text { Ischaemic } \\
\text { Heart Disease }\end{array}$ \\
\hline $55-59$ SA & Stroke & HIVIAIDS & HIVIAIDS \\
\hline $55-59$ IND & $\begin{array}{l}\text { Ischaemic } \\
\text { Heart } \\
\text { Disease }\end{array}$ & $\begin{array}{l}\text { Ischaemic } \\
\text { Heart Disease }\end{array}$ & $\begin{array}{l}\text { Ischaemic } \\
\text { Heart Disease }\end{array}$ \\
\hline $60-645 A$ & Stroke & Diabetes Mellitus & Diabetes Mellitus \\
\hline $60-64 \mathrm{IND}$ & $\begin{array}{l}\text { Ischaemic } \\
\text { Heart } \\
\text { Disease }\end{array}$ & $\begin{array}{l}\text { Ischaemic } \\
\text { Heart Disease }\end{array}$ & $\begin{array}{l}\text { Ischaemic } \\
\text { Heart Disease }\end{array}$ \\
\hline
\end{tabular}

Note: Green color is used to denote Communicable diseases; and Blue color is used to denote Non-Communicable diseases.. 
Table 12 represents the number of deaths of female per 100,000 population due to leading cause of disease in South Africa and India. Throughout there is a volatile trend in the number of deaths of females due to HIV/AIDS in South Africa in all the age groups. The number has increased in 2010 from 2000 and then declined sharply in 2019. In India although number of deaths of females in 2019 has declined from 2010 due to tuberculosis in the age group of 40-44 but in most of the age groups the cases of ischaemic heart disease is on rise in 2019 in comparison to 2010.

\begin{tabular}{|c|c|c|c|}
\hline & 2000 & 2010 & 2019 \\
\hline 40-44 SA & $\begin{array}{l}\text { HIV/AIDS } \\
615.1\end{array}$ & $\begin{array}{l}\text { HIV/AIDS } \\
731.4\end{array}$ & $\begin{array}{l}\text { HIV/AIDS } \\
216.3\end{array}$ \\
\hline 40-44 IND & $\begin{array}{l}\text { Tuberculosis } \\
54.1\end{array}$ & $\begin{array}{l}\text { Tuberculosis } \\
34.5\end{array}$ & $\begin{array}{l}\text { Tuberculosis } \\
28.2\end{array}$ \\
\hline 45-49 SA & $\begin{array}{l}\text { HIV/AIDS } \\
409.6\end{array}$ & $\begin{array}{l}\text { HIV/AIDS } \\
579.3\end{array}$ & $\begin{array}{l}\text { HIV/AIDS } \\
200.8\end{array}$ \\
\hline 45-49 IND & $\begin{array}{l}\text { Ischaemic } \\
\text { Heart Disease } \\
59.3\end{array}$ & $\begin{array}{l}\text { Ischaemic } \\
\text { Heart Disease } \\
63\end{array}$ & $\begin{array}{l}\text { Ischaemic } \\
\text { Heart Disease } \\
53.2\end{array}$ \\
\hline 50-54 SA & $\begin{array}{l}\text { HIV/AIDS } \\
256.9\end{array}$ & $\begin{array}{l}\text { HIV/ AIDS } \\
379\end{array}$ & $\begin{array}{l}\text { HIV/AIDS } \\
159.9\end{array}$ \\
\hline 50-54 IND & $\begin{array}{l}\text { Ischaemic } \\
\text { Heart Disease } \\
92.8\end{array}$ & $\begin{array}{l}\text { Ischaemic } \\
\text { Heart Disease } \\
91.2\end{array}$ & $\begin{array}{l}\text { Ischaemic } \\
\text { Heart Disease } \\
112.5\end{array}$ \\
\hline 55-59 SA & $\begin{array}{l}\text { Stroke } \\
163.1\end{array}$ & $\begin{array}{l}\text { HIV/AIDS } \\
218.9\end{array}$ & $\begin{array}{l}\text { HIV/AIDS } \\
126.9\end{array}$ \\
\hline 55-59 IND & $\begin{array}{l}\text { Ischaemic } \\
\text { Heart Disease } \\
193.1\end{array}$ & $\begin{array}{l}\text { Ischaemic } \\
\text { Heart Disease } \\
150.8\end{array}$ & $\begin{array}{l}\text { Ischaemic } \\
\text { Heart Disease } \\
175.2\end{array}$ \\
\hline 60-64 SA & $\begin{array}{l}\text { Stroke } \\
318.1\end{array}$ & $\begin{array}{l}\text { Diabetes M ellitus } \\
348.3\end{array}$ & $\begin{array}{l}\text { Diabetes } M \text { ellitus } \\
240\end{array}$ \\
\hline 60-64 IND & $\begin{array}{l}\text { Ischaemic } \\
\text { Heart Disease } \\
268.2\end{array}$ & $\begin{array}{l}\text { Ischaemic } \\
\text { Heart Disease } \\
254.5\end{array}$ & $\begin{array}{l}\text { Ischaemic } \\
\text { Heart Disease } \\
273.3\end{array}$ \\
\hline
\end{tabular}

Note: Green color is used to denote Communicable diseases; and Blue color is used to denote Non-Communicable diseases.

Source: Derived from the various tables analyzed above (Author's study)

Table 13 indicates that female of South Africa is severely affected with communicable disease in the form of HIV/ AIDS as the leading cause of mortality whereas, female of India is affected with non-communicable disease such as Ischaemic heart disease as the leading cause of deaths in the middle age group.

Figure 1 (a) indicates the number of deaths of females per 100,000 population in the age groups of 40-64. From the figure it is clear that number of deaths are high in early middle age and slowly it is decreasing in the later years reaching to 64 in South Africa. The total number of deaths increased in 2010 in comparison to 2000 but there is a sharp drop in 2019. 


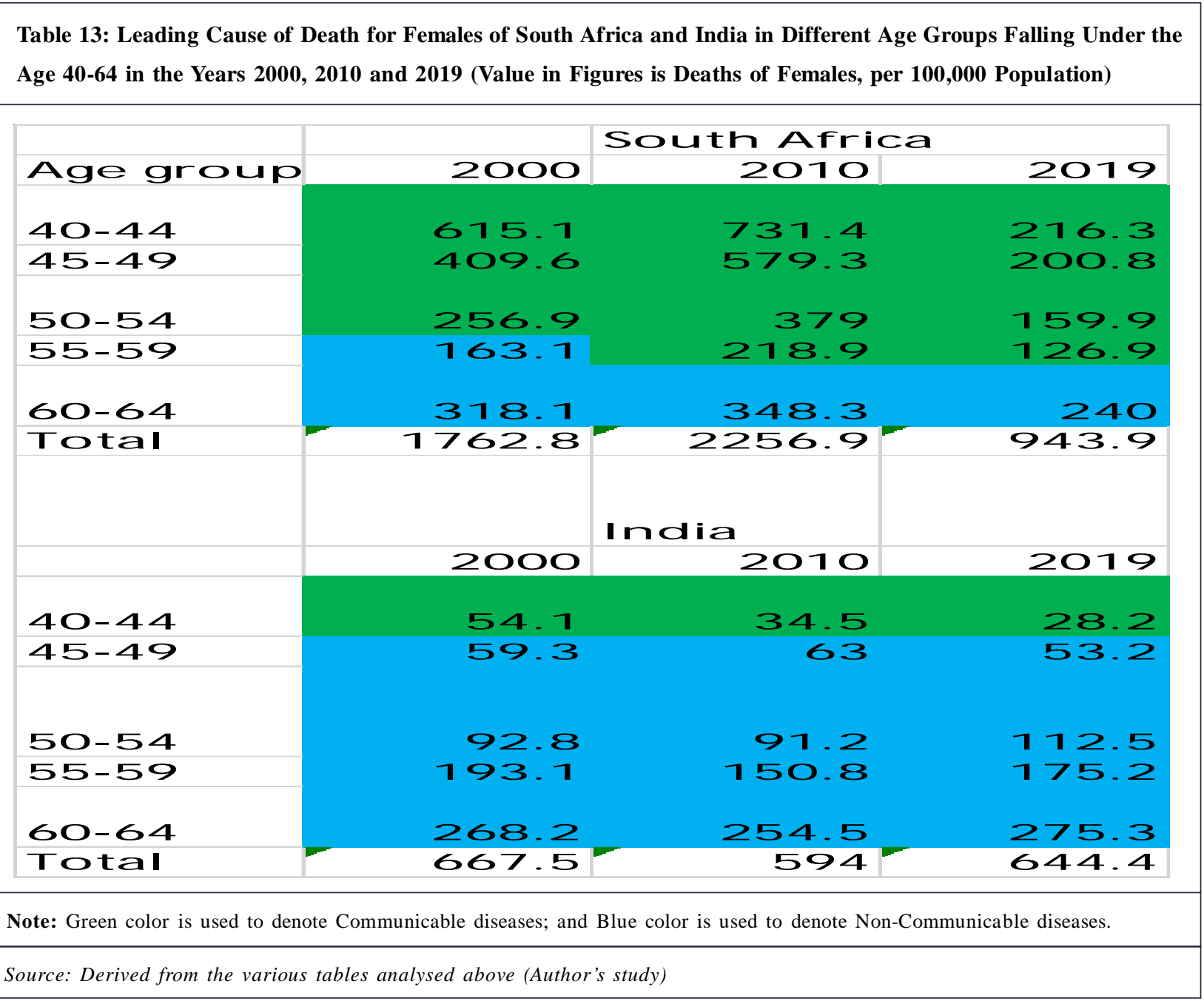

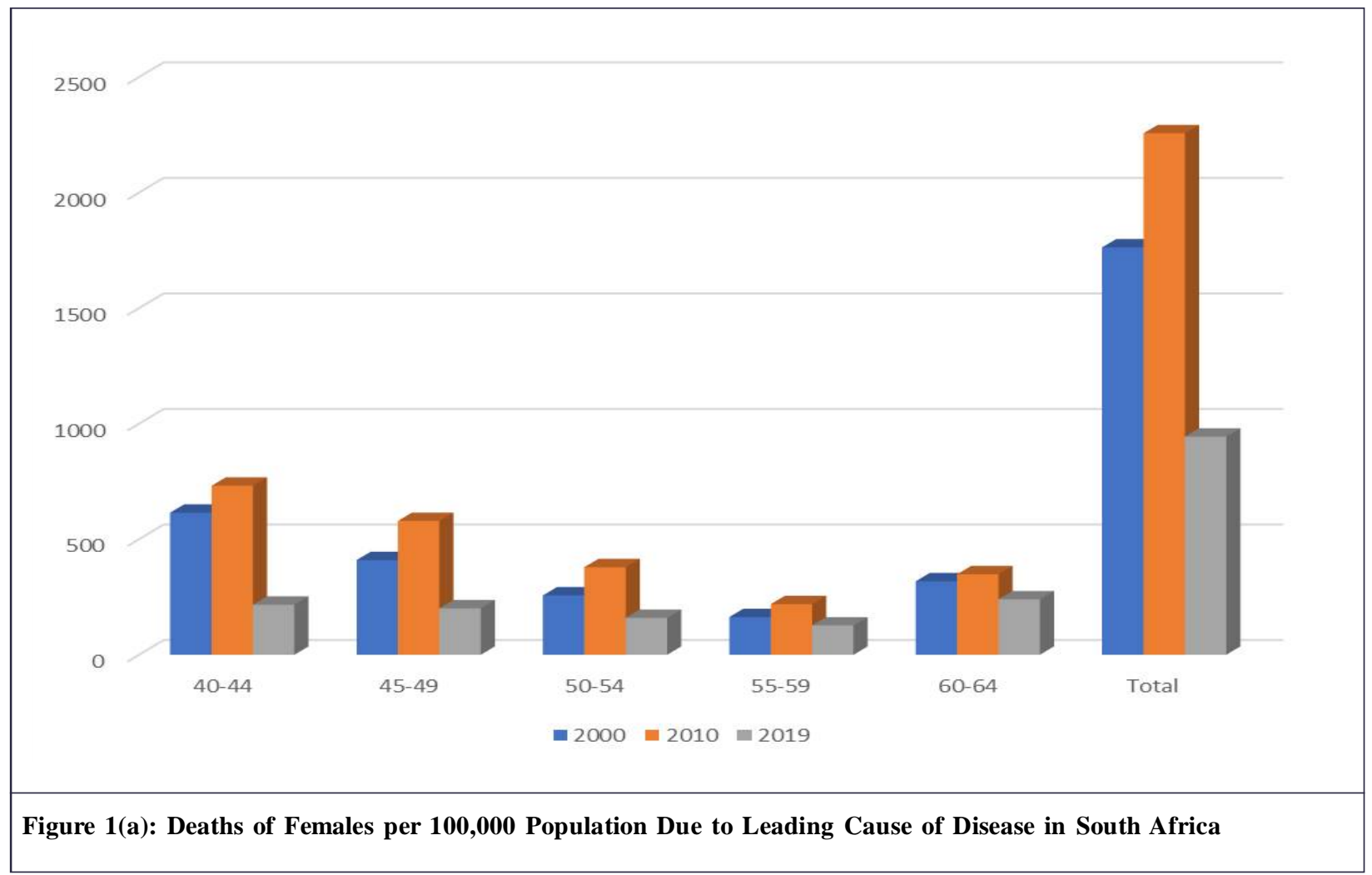


Figure 1 (b) indicates the number of deaths of females per 100,000 population in the age groups of 40-64. From the figure it is clear that number of deaths are low in early middle age and slowly it is increasing in the later years reaching to 64 in India. The total number of deaths decreased in 2010 in comparison to 2000 but then there is rise in 2019.

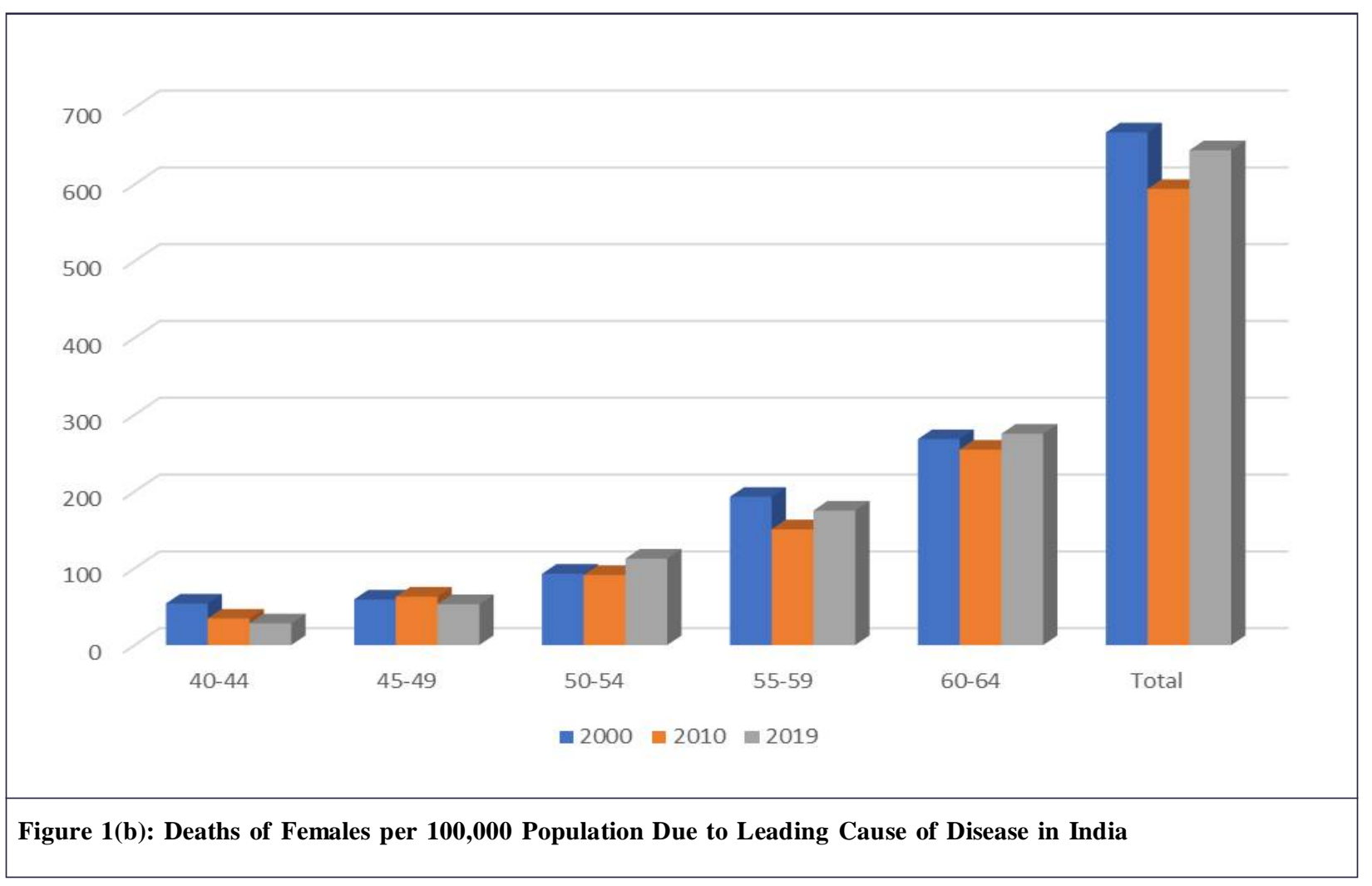

\section{Results and Discussion}

HIV/AIDS is the top reason of deaths of females in the middle age group in South Africa. Still the number of deaths of female is quite high due to this communicable disease. In the age group of 60-64 stroke and diabetes mellitus a noncommunicable disease is emerging as the leading cause of deaths of females in South Africa.

Tuberculosis is the leading cause of deaths of females in the age group of 40-44 in India but in rest of all the age groups till 64 Ischaemic Heart disease is the leading cause of deaths for females in all the three years that is 2000,2010 and 2019 and the numbers are increasing in the recent years.

In South Africa HIV/AIDS a communicable disease is the leading cause of deaths of females whereas in India Ischaemic heart disease a non-communicable disease is the leading cause of deaths of females in their middle age.

The number of deaths of females per 100,000 population is high in early years of their middle age and low in later years of the middle age in South Africa. The total number of deaths of females increased in 2010 from 2000 and then declined sharply in 2019 in South Africa.

The number of deaths of females per 100,000 population is low in early years of their middle age and high in later years of their middle age in India. The total number of deaths of females per 100,000 population decreased in 2010 from 2000 and then rose in 2019 in the country.

\section{Conclusion}

Interventions to prevent HIV/AIDS, tuberculosis and Ischaemic heart disease might address over half of the middleaged deaths of females in South Africa and India. Improved prehospital care and post hospital care might address just over a third of the deaths related to ischaemic heart diseases. Risk factors for stroke and diabetes mellitus disease are high in middle-aged females in South Africa. High levels of obesity rendering them at greater risk for metabolic disease. Reducing the negative impacts of the health transition in the middle-aged females will require targeted efforts within the health and social sectors, as well as broader development initiatives in South Africa and India. Focusing on national awareness programs about the use of protective measures, free and door to door availability of contraceptive methods, tobacco control, sugar control and stress control programs combined with access to adequate treatment, could yield 
significant gains for the middle-aged females' health in both the countries. While the specific mix of risk factors contribute to disease prevalence in different ways in South Africa and India, they should all be targeted in multi-sectoral efforts to reduce the high burden of communicable and non-communicable diseases in today's society. A need to strengthen awareness and mentorship programs for middle-aged female to control such disease related deaths is recommended.

\section{References}

Arbyn, M., Weiderpass, E., Bruni, L., de Sanjosé, S., Saraiya, M., Ferlay, J. and Bray, F. (2020). Estimates of Incidence and Mortality of Cervical Cancer in 2018: A Worldwide Analysis. The Lancet Global Health, 8(2), e191-e203.

Bigaard, J., Frederiksen, K., Tjønneland, A., Thomsen, B.L., Overvad, K., Heitmann, B. L. and Sørensen, T.I.A. (2005). Waist Circumference and Body Composition in Relation to All-Cause Mortality in Middle-Aged Men and Women. International Journal of Obesity, 29(7), 778-784.

Dagenais, G.R., Leong, D.P., Rangarajan, S., Lanas, F., Lopez-Jaramillo, P., Gupta, R., ... and Yusuf, S. (2020). Variations in Common Diseases, Hospital Admissions, and Deaths in Middle-Aged Adults in 21 Countries From Five Continents (PURE): A Prospective Cohort Study. The Lancet, 395(10226), 785-794.

Global Health Estimates (2020). Deaths by Cause, Age, Sex, by Country and by Region, 2000-2019. Geneva, World Health Organization.

Gomes, M., Begum, R., Sati, P., Dikshit, R., Gupta, P.C., Kumar, R., ... and Jha, P. (2017). Nationwide Mortality Studies to Quantify Causes of Death: Relevant Lessons from India’s Million Death Study. Health Affairs, 36(11), 1887-1895.

Houle, B., Clark, S.J., Gómez-Olivé, F.X., Kahn, K. and Tollman, S.M. (2014). The Unfolding Counter-Transition in Rural South Africa: Mortality and Cause of Death, 1994-2009. PLoS One, 9(6), e100420.

Hsiao, M., Malhotra, A., Thakur, J.S., Sheth, J. K., Nathens, A.B., Dhingra, N., ... \& Million Death Study Collaborators. (2013). Road Traffic Injury Mortality and its Mechanisms in India: Nationally Representative Mortality Survey of 1.1 Million Homes. BMJ Open, 3(8).

Kahn, K. (2011). Population Health in South Africa: Dynamics Over the Past Two Decades. Journal of Public Health Policy, 32(1), S30-S36.

Maimela, E., Alberts, M., Modjadji, S.E., Choma, S.S., Dikotope, S.A., Ntuli, T.S. and Van Geertruyden, J.P. (2016). The Prevalence and Determinants of Chronic Non-Communicable Disease Risk Factors Amongst Adults in the Dikgale Health Demographic and Surveillance System (HDSS) Site, Limpopo Province of South Africa. PloS One, 11(2), e0147926.

Matzopoulos, R., Prinsloo, M., Wyk, V.P.V., Gwebushe, N., Mathews, S., Martin, L.J., ... and Bradshaw, D. (2015). InjuryRelated Mortality in South Africa: A Retrospective Descriptive Study of Postmortem Investigations. Bulletin of the World Health Organization, 93, 303-313.

Mohan, I., Gupta, R., Misra, A., Sharma, K.K., Agrawal, A., Vikram, N.K., ... \& Pandey, R.M. (2016). Disparities in Prevalence of Cardiometablic Risk Factors in Rural, Urban-Poor, and Urban-Middle Class Women in India. PloS One, 11(2), e0149437.

Naghavi, M., Abajobir, A.A., Abbafati, C., Abbas, K.M., Abd-Allah, F., Abera, S.F., ... and Fischer, F. (2017). Global, Regional, and National Age-Sex Specific Mortality For 264 Causes of Death, 1980-2016: A Systematic Analysis for the Global Burden of Disease Study 2016. The Lancet, 390(10100), 1151-1210.

Nojilana, B., Bradshaw, D., Pillay-van Wyk, V., Msemburi, W., Laubscher, R., Somdyala, N. I., ... and Dorrington, R.E. (2016). Emerging Trends in Non-Communicable Disease Mortality in South Africa, 1997-2010. South African Medical Journal, 106(5), 477-484.

Pandey, R.M., Gupta, R., Misra, A., Misra, P., Singh, V., Agrawal, A., ... and Sharma, V. (2013). Determinants of UrbanRural Differences in Cardiovascular Risk Factors in Middle-Aged Women in India: A Cross-Sectional Study. International Journal Of Cardiology, 163(2), 157-162.

Patra, S. (2016). Motherhood in Childhood: Addressing Reproductive Health Hazards Among Adolescent Married Women in India. Reproductive Health, 13(1), 1-9.

Pearce, A., Sharp, L., Hanly, P., Barchuk, A., Bray, F., de Camargo Cancela, M., ... and Soerjomataram, I. (2018). Productivity Losses Due to Premature Mortality from Cancer in Brazil, Russia, India, China, and South Africa (BRICS): A Population-Based Comparison. Cancer Epidemiology, 53, 27-34. 
Ram, U., Jha, P., Gerland, P., Hum, R.J., Rodriguez, P., Suraweera, W., ... and Ram, F. (2015). Age-Specific and Sex-Specific Adult Mortality Risk in India In 2014: Analysis of 0. 27 Million Nationally Surveyed Deaths and Demographic Estimates from 597 Districts. The Lancet Global Health, 3(12), e767-e775.

Ruan, Y., Guo, Y., Zheng, Y., Huang, Z., Sun, S., Kowal, P., ... and Wu, F. (2018). Cardiovascular Disease (CVD) and Associated Risk Factors Among Older Adults in Six Low-and Middle-Income Countries: Results From SAGE Wave 1. BMC Public Health, 18(1), 1-13.

Sil, A. and Dhillon, P. (2021). Modelling Determinants of Deaths Attributable to External Causes Among Adults in India. OMEGA-Journal of Death and Dying, 00302228211009736.

Cite this articleas: Uma (2021). Differences and Similarities: A Study of Pattern of Disease Related M ortality in M iddle-A ged Females of South A frica and India. International J ournal of A frican Studies. 1(4), 25-41. doi: 10.51483/ IJAFRS.1.4.2021.25-41. 